\title{
THE CATTLE EGRET ARRIVES IN SASKATCHEWAN
}

DALE G. HJERTAAS, Fisheries \& Wildlife Branch, Saskatchewan Dept. of Tourism \& Renewable Resources, 2602 - 8th Street East, Saskatoon, Saskatchewan, S7H 0V7.

The Cattle Egret, a native of Africa, Asia and southern Europe, has expanded its range dramatically in the last century to include North and South America and Australia. The species established in South America in the 1930's, or possibly earlier. Crosby 4 has shown that the first North American birds, those photographed in southern Florida in 1952 and found nesting in the same area in 1953, were probably immigrants from the expanding South American population.

From this beginning, the Cattle Egret has greatly increased its numbers and range on this continent. In 1954 they nested for the first time in Northern Florida.14 By 1962, only 9 years after its first recorded nesting in the U.S.A., it was established intermittently along the coast from Texas to Maryland and along the Great Lakes in Ontario (Fig. 1). By 1970 it had filled the gaps in its coastal range, moved inland and spread north along the Mississippi Valley. It had also reached California, apparently crossing Mexico at the Isthmus of Tehuantepec in the mid1960's, and moving up the Pacific Coast to establish a colony at the Salton Sea in 1970.4

The first Canadian record was in 1952 when one was recorded on the Grand Banks of Newfoundland. 6 Since then, Cattle Egret records have been obtained for most provinces and even the Northwest Territories. 12 The first prairie records were one near Brandon, Manitoba, in 1961 and one near Iron Springs, Alberta, in November, 1964.15 The first Canadian breeding records were at two localities in southern Ontario in 1962.3 In subsequent years, small numbers bred along Lake Ontario and Lake Erie, principally at Pigeon Island near Kingston and Pelee Island at Canada's southern tip.

The range and population expansion of this species is continuing. By 1976 the Florida breeding population had increased to 200,000 pairs, making the Cattle Egret that state's most abundant heron only 27 years after it first nested there.13 Fig. 1 shows how, to 1978 , the range has extended farther north and inland in New England, into Northern California, across the southern Great Plains into Arizona, Utah and Idaho, and up the Mississippi Valley into Wisconsin, Minnesota and the Dakotas. North Dakota's first nest records were 15 nests in 1976 and 11 in 1977 at J. Clark Salyer National Wildlife Refuge, $50 \mathrm{~km}$ southeast of Saskatchewan. 11

\section{The Cattle Egret in Saskatchewan}

Two Cattle Egrets reported by Hugh H. Hedger at the Nis'ku Goose Project near Eyebrow on 14 to 17 June, 1974, provided the first record in Saskatchewan. 9 On 28 July, 1977, the author obtained the second Saskatchewan record when two egrets were seen sitting on old 


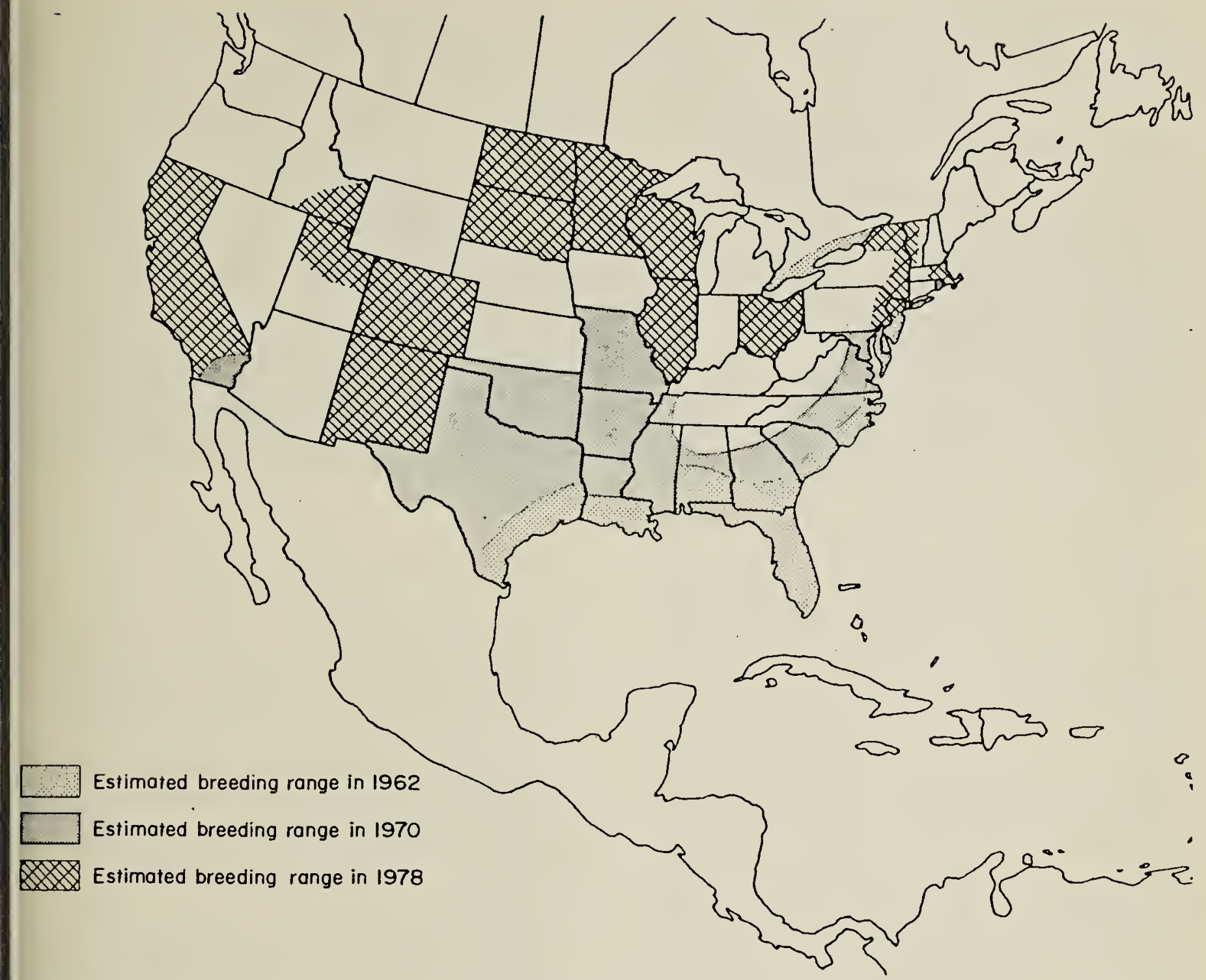

Figure 1: Estimated breeding range of the Cattle Egret in Canada and the United States in 1962, 1970 and 1978. (Based on Nesting Season Reports in American Birds from 1959 to 1978.$)$

bridge pilings beside Long Creek 1 mile west of Maxim on SE 30-4-15W2. They flushed to join four others feeding with cattle in pasture on the same quarter section beside Long Creek. I obtained identifiable photographs of these birds to confirm a new species in Saskatchewan.

At least two of the six birds were in breeding plumage. On 4 August, I observed seven in the area of which six were in breeding plumage and on 23 August, 10 Cattle Egrets were present. On each occasion they fed in the same small pasture with the same cattle. They usually walked beside a cow, catching insects disturbed by its movement. When I was too close to the cattle, the egrets would feed on their own but returned to the cattle as soon as I moved away. These egrets were also observed and photographed by other birders, including Fred Lahrman and Wayne C. Harris. I revisited the area in hope of finding a nest on 27 June, 1978 , but was unable to locate any egrets.

Fig. 2 shows locations of six records of the Cattle Egret in Saskatchewan. John Toten of the U.S. Fish and Wildlife Service saw up to seven at the Ding Darling Ducks Unlimited Project near Little Quill Lake several times during August 1977.7

In 1978, two Cattle Egrets were observed near Richardson from 22 to 29 May, one near Saskatoon on 27 and 28 May, 8 and three in non-breeding plumage at Kinistino on 8 June, ${ }^{16}$ 
providing the fourth, fifth and sixth Saskatchewan records.

\section{Rapid Spread in North America}

Several features of the biology of the Cattle Egret have facilitated its population expansion in North America since 1953. These can be divided into behavioural adaptations which allow pioneering to a new area, and adaptations which allow successful establishment and reproduction in the new site.

Post-breeding wandering is common in Cattle Egrets, especially among juveniles, as it is in many herons. This wandering can lead to colonization of new areas and may be the mechanism of dispersal from Africa to South America. ${ }^{2}$ Rice ${ }^{14}$ suggests migration with other heron species leads Cattle Egrets to new heronries outside its previous range. $\mathrm{He}$ believes the Cattle Egret would not nest in colonies of its own kind smaller than ten pairs, but even lone pairs can establish in colonies of other species.

The success of colonization attempts indicates the Cattle Egret is filling a vacant feeding niche. It feeds in grasslands, usually away from water. It prefers to walk near a grazing cow and catch grasshoppers, its most important food item, and other prey flushed by the grazing animal. 10 Although Cattle Egrets also feed by themselves, they are 3.6 times more efficient when feeding with a large animal. ${ }^{5}$ Rice ${ }^{14}$ believes this increased efficiency is essential for the species' successful reproduction.

Jenni10 showed that Cattle Egrets raised more young per pair than Louisiana Herons, Little Blue Herons or Snowy Egrets in the same colony because they were able to provide more food and raise all their chicks. The youngest chick usually starves

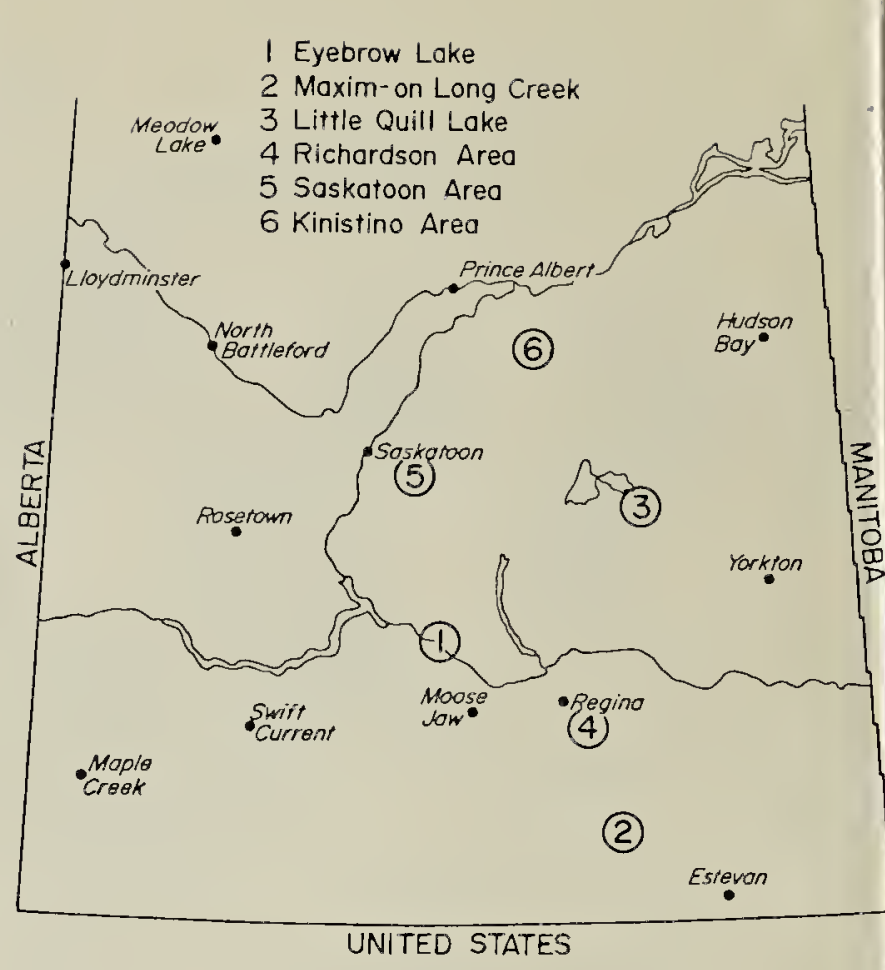

Figure 2: Locations of the first six records of the Cattle Egret in Saskatchewan.

in nests of the other species. Jenni concluded that the Cattle Egrets had. tapped a feeding niche where they did not compete with other heron species.

Their need to feed with large animals may also account for the Cattle Egret's failure to colonize the Americas hundreds of years ago. 1 No large grazing mammals were indigenous to the American tropics. Thus, it is only since European settlement and establishment of a cattle industry that Florida, Central America and northern South America provided suitable habitat for Cattle Egrets. When a cattle industry had been established and pasture land provided suitable feeding areas, it was simply a matter of time before Cattle Egrets successfully crossed the Atlantic and colonized America.

\section{Future in Saskatchewan}

Successful nestings in North Dakota suggest the Cattle Egret will continue to appear in Saskatchewan and will probably be found nesting within a few years. Observers should watch for this species, particularly where existing heron colonies are 


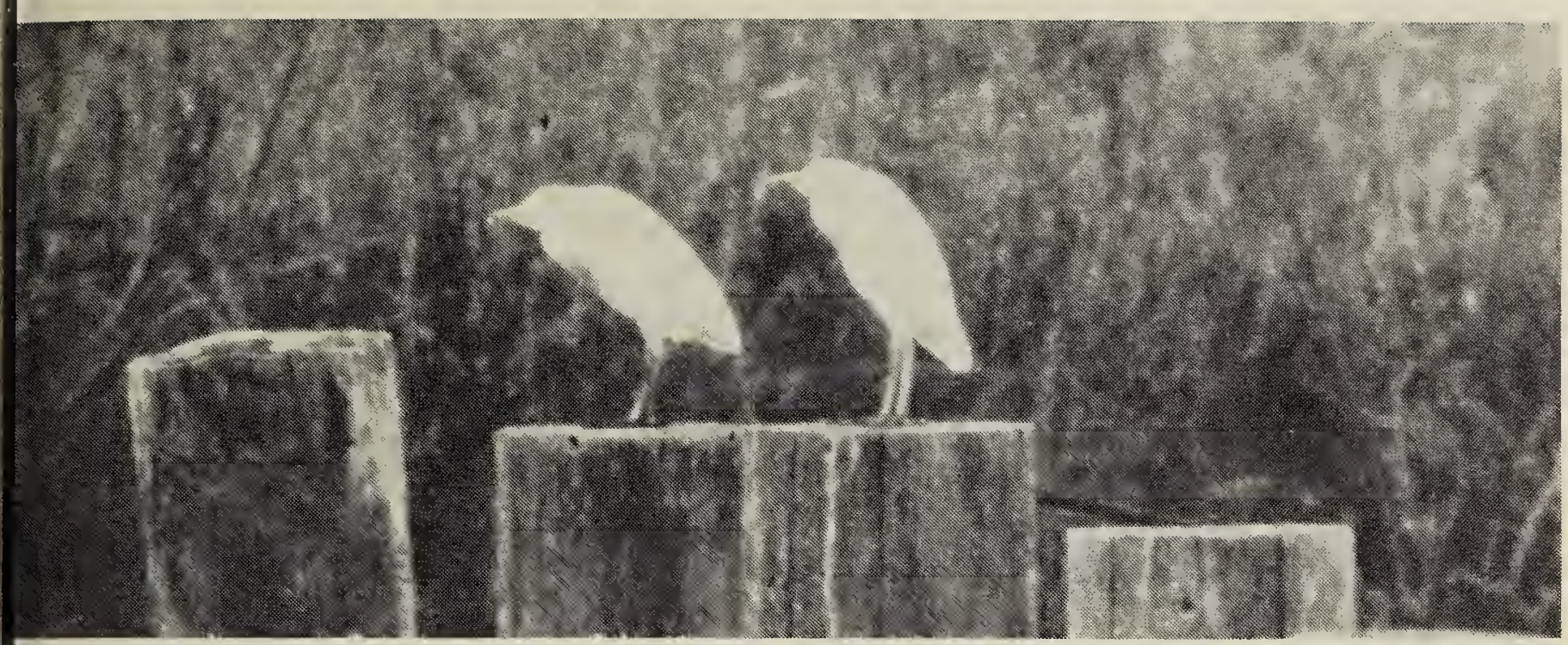

Dave Duffus

lose to moist, moderately grazed pastures which provide preferred eeding areas for the egrets.

While herons do show interspecific erritoriality and compete for nest sites and materials, the Cattle Egret should not have adverse effects on populations of Great Blue Herons and Black-crowned Night Herons in Saskatchewan because nest sites are not limiting in most colonies, and he Cattle Egret uses a different eeding niche than other herons.

I am grateful to George Duff, J. B. Gollop, C. S. Houston, W. J. Maher, and Verna MacKinnon for assistance n preparing this manuscript.

1BLAKER, D. 1971. Range expansion of the Cattle Egret. Ostrich Suppl. 9:2730.

2BROWDER, J. A. 1973. Long-distance movements of Cattle Egrets. BirdBanding 44:158-70.

${ }^{3}$ BUERKLE, V., and W. D. MANSELL 1963. First nesting record of the Cattle Egret (Bubulcus ibis) in Canada. Auk 80:378-79.

${ }^{4}$ COSBY, G. T. 1972. Spread of the Cattle Egret in the Western Hemisphere. Bird-Banding 43:205-12.

5 DINSMORE, J. J. 1973. Foraging success of Cattle Egrets, Bubulcus ibis. Am. Midland Nat. 89(1):242-46.
6GODFREY, W. E. 1966. The birds of Canada. Nat. Mus. Canada Bull. No. 203, Ottawa.

7GOLLOP, J. B. 1978. White-faced Ibis and Cattle Egret at Little Quill Lake. Blue Jay 36:122.

8GOLLOP, J. B. 1978b. Saskatchewan nesting season, 1978. Unpublished report.

9HOUSTON, C. S., and M. I. HOUSTON 1974. The nesting season: June 1, 1974 - July 31, 1974, Northern Great Plains. Am. Birds 28:915-18.

10JENNI, D. A. 1969. A study of the ecology of four species of herons during the breeding season at Lake Alice, Alackua County, Florida. Ecol. Monogr. 39:245-70.

11JONES, L. A., and J. M. MALCOM 1978. First nesting record of Cattle Egret and Little Blue Heron in North Dakota. Prairie Naturalist 10:122.

12KUYT, E. 1972. First record of the Cattle Egret in the Northwest Territories. Can. Field-Nat. 86:83-4.

13OGDEN, J. C. 1976. The nesting season: June 1 - July 31, 1976, Florida Region. Am. Birds 30:945-48.

14RICE, D. W. 1956. Dynamics of range expansion of Cattle Egrets in Florida. Auk 73:259-66.

15SALT, W. R., and J. R. SALT 1976. The birds of Alberta. Hurtig Publishers, Edmonton.

16SERR, E. M. 1978. The nesting season: June 1 - July 31, 1978, Northern Great Plains Region. Am Birds 32:1175-78. 